\title{
Short Comment on the Current Understanding of Ecological Behavior of Metal Azo Dyes and the Case for Proactive Wastewater Treatment
}

\author{
Philip CW Cheung* and Daryl R Williams \\ Department of Chemical Engineering, Imperial College, UK
}

Submission: November 11, 2017; Published: October 01, 2018

*Corresponding author: Philip CW Cheung, Department of Chemical Engineering, Imperial College, South Kensington, London, United Kingdom;

Email: philip.cheung@imperial.ac.uk

\begin{abstract}
The relative non-toxic metal azo dyes present in wastewaters may be transported to long-distances where the metallic ion and the azo ligand may separate and manifest their own ecotoxicities. The environmental factors which can affect this may be too complex to monitor, and the case of on-site treatment at dye manufacturing or textile facilities is developed in this narrative. A simple mono-azo dye, namely, Eriochrome Black $\mathrm{T}$, is introduced to illustrate molecular structures of metal azo dyes and possible candidate for ad hoc, preliminary testing of future treatment methods.
\end{abstract}

Keywords: Metal azo dye; Eriochrome black T; Ecotoxicology; Wastewater treatment

\section{Introduction}

Ever since the synthesis of the first metallizable azo dye, alizarin yellow, from diazotized 4-nitroaniline and salicylic acid by the German chemist Rudolf Nietzki in 1887, followed by the synthesis of the first metallizable 2-2'-dihydroxy azo dye by E. Bergmann and 0. Borgmann in 1893 [1,2] dyes formed as a result of the chelation of a metallic ion by an aromatic o, o-dihydroxy azo compound have generated continuous commercial interest [3]. Famous for their lightfastness (great resistance to fading in sunlight), the so-called "metal-complex dyes" have a great number of applications. Apart from a few restrictions affecting a handful of synthetic fibres, the dyeing industries are satisfied that virtually all substrates can be printed or dyed by them, with a dull shade. In fact, many shades of yellowish-green can be attained by mixing these dyes. The dyeing industries continually search for new shades by mixing different dyes and observing the resulting color. New metal azo dyes are continuously being synthesized and reported, e.g., Myek et al. [4] synthesized a new azo dye and its iron complex with the organic ligand being 3-aminophenol; Van et al. [5] produced a set of novel complexes of bispyrazole azo dyes for chemical fibers, each dye containing one of these metallic ions: $\mathrm{Ag}^{+}, \mathrm{Fe}^{3+}, \mathrm{Co}^{2+}, \mathrm{Ni}^{2+}$ or $\mathrm{Cu}^{2+}$; Hussain et al. [6]; El-Wakiel [7]. Herbst \& Hunger [8] illustrated the two theoretical structures of an azo-metallic chelate, Figure 1 . The nitrogen atom bonded to the least nucleophilic aromatic moiety is usually the one that donates its lone pair of electrons to the metallic ion.
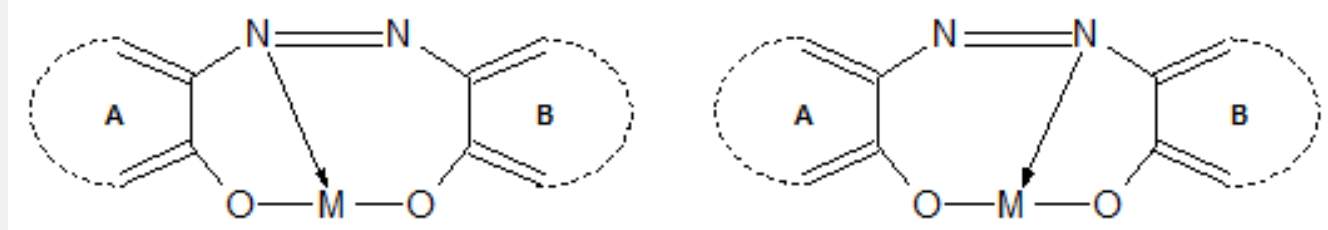

Figure 1: Two possible ways for an azo dye to complex a metallic ion [8].

\section{An Illustrative Model Structure}

"Eriochrome Black T" (also known as Mordant Black 11, and hereafter abbreviated to EBT) is a water-soluble mono-azo dye and also a complexing ligand for metallic ions. EBT has many applications, e.g., Dave et al. [9] reported that EBT is used to dye silk, wool and nylon after treatment with Cr (III) salts. In fact, it is highly likely that the chelated complex $\mathrm{Cr}$ (III)-EBT will form [10]. Non-complexed EBT can be obtained commercially 
(as its sodium salt), the IUPAC name of which is 3-hydroxy-4(1-hydroxy-2-naphthylazo)-7-nitro-1-naphthalene sulfonic acid, and its anion (the dye) is shown in Figure 2. EBT is triprotic, the dissociation of the sulfonic acid group being complete. An aqueous solution is red when $\mathrm{pH}<6$, blue at $\mathrm{pH}=7$ to 11 , and orange when $\mathrm{pH}>12$. These colorations can be readily observed in the laboratory on titration with $\mathrm{NaOH}$.

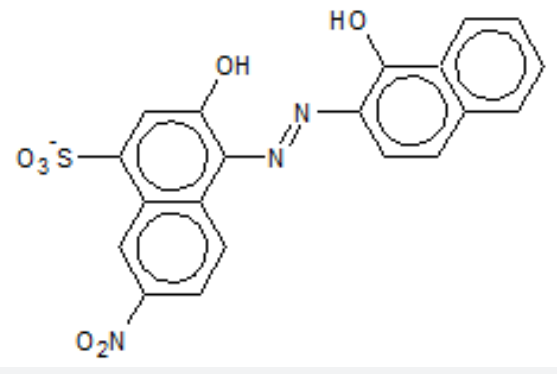

Figure 2: Molecular Structure of Eriochrome Black T [12].

The indicator is formulated as $\mathrm{H}_{2} \mathrm{In}^{-}$and the two further dissociations of the phenolic groups are [11]:

$\mathrm{H}_{2} \mathrm{In}^{-} \rightarrow \mathrm{H}^{+}+\mathrm{HIn}^{2-} \quad \mathrm{p} K_{2}=6.3$ [dissociation on the right-hand ring system]

\section{Red Blue}

$\mathrm{HIn}^{2-} \rightarrow \mathrm{H}^{+}+\operatorname{In}^{3-} \quad \mathrm{p} K_{3}=11.6$ [dissociation on the sulfonate ring system]

Blue Orange

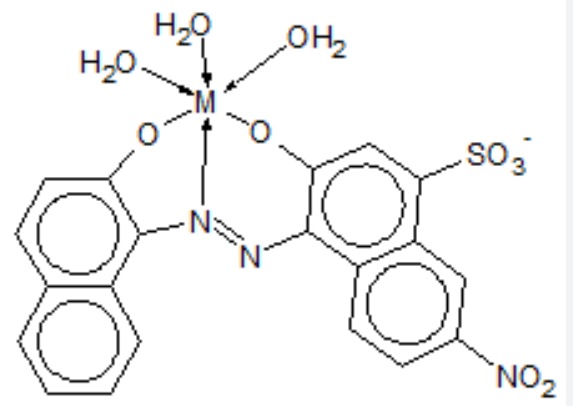

Figure 3: A proposed structure for Ni (II)-EBT [14].

The changes in the colour of EBT as a function of $\mathrm{pH}$ reflect the large $\mathrm{pH}$ range practiced in the dyeing of textiles (Figure 2) [12]. Also, with a relatively low molecular mass of 461.38 and only one naphthalene group attached to each nitrogen atom, EBT is simple in structure compared to dyes with higher molecular masses. Preliminary R\&D of wastewater treatment methods would be more difficult for di- or tri- azo dyes (i.e., dyes with two and three $-\mathrm{N}=\mathrm{N}$ - linkages per molecule) with molecular masses exceeding 1,000, because it would not be easy to determine if or which of the azo linkages are fractured. Therefore, EBT is a good model compound for preliminary studies of chemical reactions leading to decolourization of azo and metal-azo dyes in wastewaters (in addition that much is known about the dye already). Titration exercises in the laboratory using EBT as an indicator resulted in wastewaters requiring treatment so that they would not render other aqueous wastes colorful and nondisposable when they are mixed in wastewater tanks awaiting disposal. Both the acid-base and the tautomeric azo-hydrazone equilibria of EBT in organic solvents were recognised by Hamed et al. [13] using electronic absorption spectroscopy. Çakir et al. [14] proposed the following structure for the Ni(II)-Eriochrome Black T chelated complex, hereafter designated as the "Ni(II)EBT complex", (Figure 3). The formation constants of some other metal-EBT chelated complexes are tabulated on Table 1. The problem of tautomerism does not enter into structural determination of the complex because both hydroxyl groups of the EBT molecule are ionized, leaving the negatively charged oxygen atoms to bond with a positively charged metallic ion. Çakir et al. [15] observed the formation of two complexes with stoichiometric ratios of [EBT]: $\left[\mathrm{Ni}^{2+}\right]$ being $1: 1$ and $2: 1$ respectively (with formation constants $\log 10 K_{1}=8.17$ and $\log 10 K_{2}=11.17$ ). However, the structure of the $2: 1$ complex was not diagrammed in their paper. Herbst \& Hunger [16] presented the molecular structure of (the intensely yellowish green) "Pigment Green 10" of stoichiometry 2 dye ligands to $1 \mathrm{Ni2+}$ ion [16]. Unlike the 2:1 EBT complex, the two-organic monoazo ligands are different molecules, namely p-chloroaniline and 2,4-dihydroxy-quinoline; each have two hydroxyl groups but only the ionised hydroxyl group in each is involved in chelating $\mathrm{Ni}^{2+}$. Note the formation of two closed rings with the single nickel ion and the donation to it of a total of two lone pairs of electrons by nitrogen atoms. This is illustrated on Figure 4. The synthesis, stereochemistry, speciation and performance of the azo dyestuffs of chromium, iron, cobalt, nickel and copper are discussed in great detail in three separate treatises by Hunger [17], Zollinger [18], and Herbst, Hunger [19].

Table 1: $1^{\text {st }}$ formation constants of metal-EBT chelates in mixed solvent $(50 / 50 \mathrm{H} 2 \mathrm{O} / \mathrm{EtOH})$ at $25^{\circ} \mathrm{C}[15]$.

\begin{tabular}{|c|c|}
\hline Metallic ion & Log10Kf \\
\hline Fe (III) & 7.52 \\
\hline $\mathrm{Co}(\mathrm{II})$ & 6.64 \\
\hline $\mathrm{Ni}(\mathrm{II})$ & 6.18 \\
\hline $\mathrm{Cu}(\mathrm{II})$ & 7.29 \\
\hline $\mathrm{Zn}(\mathrm{II})$ & 5.18 \\
\hline $\mathrm{Cd}(\mathrm{II})$ & 3.91 \\
\hline $\mathrm{Pb}(\mathrm{II})$ & 4.67 \\
\hline $\mathrm{Hg}(\mathrm{II})$ & 3.47 \\
\hline
\end{tabular}

\section{Ecotoxicology}

In a fundamental and generic sense, Holdgate [20] has defined a pollutant as a "wrong" physical or chemical agent that happens to be at the "wrong place, the wrong time, in the wrong amount" [20]. Origins of pollutants must then include both arthropogenic and anthropogenic sources. Often, the later 
instigates the former, as in the infamous case of mining for copper, lead and zinc in the Japanese prefecture of Toyoma in the 1910s, with the result that the cadmium in the mine runoffs followed the course of the Jinzugawa River into the rice fields. Unfortunately, the river water was used for irrigation and this caused the disease "itai itai", a debilitating bone disease which has many side-effects and causes severe pain [21,22]. A copper mine is not one until one mines the copper! The adverse effects of metals (from all industrial sectors) and separately, of synthetic dyes on soils, plants, humans and other living organisms are well documented. The literature is profuse. Broadly, the genre falls into four main categories. Here is just a small sample:

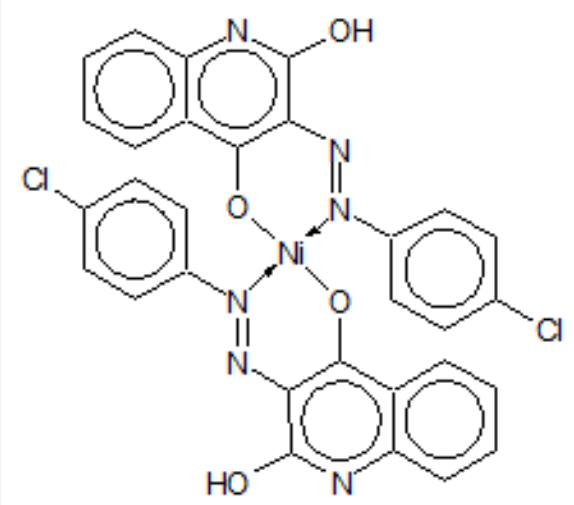

Figure 4: "Pigment Green 10" with two dye ligands to one Ni (II) ion stoichiometry [16].

1) Damage caused solely by metallic ions. Yadav et al. [23] demonstrated that urease activity and the rates of ammonification and nitrification in soil were depreciated by a series of metallic ions in the following decreasing order: $\mathrm{Ag}^{+}$, $\mathrm{Hg}^{2+}>\mathrm{Cu}^{2+}>\mathrm{Cd}^{2+}>\mathrm{Co}^{2+}>\mathrm{Ba}^{2+}>\mathrm{Zn}^{2+}>\mathrm{Ni}^{2+}>\mathrm{Fe}^{2+}>\mathrm{Cr}^{3+}>\mathrm{Mn}^{2+}$ $>\mathrm{Sr}^{2+}>\mathrm{Pb}^{2+}>\mathrm{Al}^{3+}$ [23]. Overall, the efficient use of nitrogen, an element essential to plant growth, is compromised. Damage caused by non-metallic dyes.

2) Damage caused solely by non-metallic colorants. $\mathrm{Hu}$, $\mathrm{Wu}$ [24] isolated the nitrogen-fixing cyanobacteria Anabaena sp. from the Da-Jia Brook in Taiwan only to discover that the nitrogen content in an azo dye called "RP2B" cannot be "fixed", but the growth of the bacteria itself is inhibited by the dye [24]. Batool et al. [25] also reported the inhibition of ammonium oxidation in soils by high doses of the azo dye "Reactive Black 5" [25]. The toxic properties of the metabolites of the water-soluble azo dye Methyl Red was reported by Ayed et al. [26].

3) Colorants as occupational hazards. It is now accepted in the medical and epidemiological fields that azo dyes, which, by reduction (cleavage) of their azo groups $(-\mathrm{N}=\mathrm{N}-)$ by hydrogen, produce many carcinogenic aromatic amines. The four most prominent ones are all "Category 1" carcinogens in the European Union jurisdiction [27]:

A. 4-aminodiphenyl/xenylamine/Biphenyl-4-ylamine (CAS no. 92-67-1)

\section{B. Benzidine (CAS no. 92-87-5) \\ C. 4-chloro-o-toluidine (CAS no. 95-69-2) \\ D. 2-naphthylamine (CAS no. 91-59-8).}

The 1970s landmark case of benzidine-producing azo dyes causing bladder cancer in Japanese kimono painters who licked their paint brushes to produce a fine tip (thereby ingesting the azo dyes) is well known; but it is also found that some of these toxic dyes are biodegradable [28-30]. Epidemiological studies also found elevated incidences of bladder cancer in artists, painters and printmakers in USA, a little later, in the 1980s [31-33]. A rare piece of literature but useful to chemical engineers performing environmental impact analysis of their manufacturing plants addresses the "mutagenic and carcinogenic potential of a textile azo dye processing plant effluent that impacts a drinking water source" [34].

A friendly and important reminder to the reader is that two updated standards used for the determination of restricted aromatic amines (derived from azo dyes used in textiles) were published by the European Standard Committee in February 2017; the procedure known as "EN 14362-1/3:2017" replaces standards published in 2012 [35,36]. The new documents lay out improved analysis and guidance for the interpretation of test results.

National/Regional panorama reports on environmental pollution. Zhou [36] reported that, as a result of irrigating with dye and textile effluents, organic compounds had polluted agricultural land along the coasts of mainland China and that these contaminants were distributed amongst plant tissues through internal transport [37]. Fang et al. [37] discovered the hormonal-disrupting and genotoxic effects on aquatic organisms induced by effluents from the following industries in the Pearl River Delta:

(a) Textile and dyeing facilities

(b) Electroplating and electronic (manufacturing) factories

(c) Pulp and paper mills

(d) Fine chemicals manufacturing

(e) Sewage treatment plants.

Genotoxicities were expressed as "equivalence of $\mathrm{x}$ micrograms of benz- $\alpha$-pyrene", with $88.2 \mu \mathrm{g} /$ litre as the highest reading, and an overall average of $8.76 \mu \mathrm{g} / \mathrm{litre}$ [38]. What about metal azo dyes? The ions $\mathrm{Cr}^{3+}, \mathrm{Co}^{3+}, \mathrm{Ni}^{2+}$ and $\mathrm{Cu}^{2+}$ are the most used metallic ions as they confer great stability to the complexes formed with their azo dye ligands. However, the chemistry of the chelated complex, the dye itself, is not a mere summation of the independent properties of the metal ion and the dye ligand. The metal azo dye is a unique chemical compound with respect to its biological behavior, and literature discussing the in vivo behavior of metal-azo dyes in biological systems is sparse. 
Clarke \& Anliker [38] analyzed fish toxicity data available at the time for over 3000 dyes, of which only 27 dyes exhibit LC50 of < 1ppm; these 27 dyes include 4 acid dyes, 16 basic dyes and only 7 metal-complex dyes [39]. Wastewaters which have been properly treated, i.e., to become a colorless and transparent liquid would have attained these sub-ppm concentrations, since, as a rule-of-thumb, a concentration of most dyes greater than 1 ppm will be visible to the naked eye. Brown et al. [39] observed that toxicity to algae and inhibitory effects on clarified sludge bacteria are negligible. Pollutants in the study include the free metallic ion, the ligand and the chelated metal complex [40]. Examined a published list of dyes classified as toxic (LD50 $\leq 200 \mathrm{mg} / \mathrm{kg}$ of human body mass) and found that no metalcomplex dyes were included; in fact most metallic dyes have LD50 $\geq 2000 \mathrm{mg} / \mathrm{kg}$ [41]. Many researchers are satisfied that metal-azo dyes demonstrate only slight toxicity to humans [39].

All dyes enter natural ecosystems by three routes: during the synthesis and manufacturing of dyes including waste waters, during dyeing of textiles, and during the use of finished products. The fate of the metal-azo moiety in the natural environment needs be addressed if proper risk assessments were to be carried out. This is a most difficult task because the major degradation processes are influenced by many environmental variables.

\section{The Case for Proactive Wastewater Treatment}

All dyes enter natural ecosystems by three routes: during the synthesis and manufacturing of dyes including wastewaters, during dyeing of textiles, and during the use of finished products. The fate of the metal-azo moiety in the natural environment is largely unknown. This is a difficult task because the major degradation processes are influenced by many environmental variables. Conventional "wisdom" is such that dyes are adsorbed onto activated sludge during sewage treatment and anaerobic reduction in the sediment is a relatively rapid process. In the specific case of metal-azo dyes, it remains unknown whether the metallic ions are released or stays within the complex structure with modified ligands, but refractory metal-azo dyes will find their way into natural bodies of water. In surface water, these degradation processes may take place, all affected by $\mathrm{pH}$ and temperature of the receiving waters and the structure and bonding of the dye

1) Photolysis (rate determined by sunlight intensity, i.e., "solar flux")

2) Biodegradation by bacterial enzymes

3) Chemical reactions with other species in aqueous solution

4) Hydrolysis

5) Adsorption onto particulates and surfaces.

In ground (cavern) water, there will be little or no photolysis but the other processes can take place. In soil, the situation is ever more complex. Moisture content of the soil and type of soil is an important factor in determining the fate of organic materials. The $\mathrm{pH}$ value and temperature of soil waters dictate the extent of biodegradation, chemical reactions and hydrolysis. When the soil is loamy, organic substances are retained in the soil for longer periods of time than sandy soils. Leached dyes join the cacophony of events taking place in surface and ground waters eventually. Are the dye ligands carriers for long-distance transport for metallic ions, until which time the complexes are degraded, and the metallic ions regurgitated? There is scant data. There is indeed a similar case with metalEDTA complexes in wastewaters produced by electroless plating during the manufacturing of electronic circuit boards, resulting in the development of methods for the extraction of these metals before sewering. The concern was that de-chelation by various complex forces in the environment such as the ones discussed above may release both the metallic ion and the ligand, both of which may be ecotoxic. Gorzka et al. [41] claimed that $\mathrm{Cr}^{3+}$ ions were precipitated from two di-azo dyes by addition of Ca $(\mathrm{OH})_{2}$ to the effluent, the precipitate being $\mathrm{Ca}\left(\mathrm{CrIIIO}_{2}\right)_{2}$ [42]. Although $\mathrm{Ca}(\mathrm{OH})_{2}$ is inexpensive, it is only sparingly soluble. Attempts to precipitate metallic ions from their various chelated complexes by addition of $\mathrm{Ca}(\mathrm{OH})_{2}$ were futile. Mrotzeck et al. [43] claimed in their patents to use a variety of ligands to exchange for the dye ligand, precipitating the metallic ion as a result, but it seems that the problem posed by the colour of the dye ligand in effluents remained unsolved by this group [43]. The reader is referred to the review paper by Cheung \& Williams [43] for solving this problem [44]. Cerjan Stefanović et al. [44] resorted to adsorption of metal-azo dyes $\left(\mathrm{Cu}^{2+}\right.$ and $\left.\mathrm{Cr}^{3+}\right)$ by Croatian clinoptilolite, a natural zeolite [45]. Lee \& Guthrie [45] decolorized the three mono-azo metal dyes Irgalan Grey GLN, Irgalan Black RBLN and Irgalan Blue 3GL by bacterial cells of the Shewanella strain J18143.

The authors of this article advocate achieving all the following three objectives in treating wastewaters containing metallic azo dyes:

1) Decolorize the wastewater

2) Extract the metallic ions out of solution

3) Mitigate or destroy the potential for carcinogenicity by dismantling the dye moiety.

Using the metal complexes of Eriochrome Black T is a good commencement point for the training of personnel to cope with azo dyes with higher degrees of structural complexity.

\section{Conclusion}

While the relatively scare literature concerning the behavior of metal azo-dyes towards biological systems indicates that they are much less toxic than the un-complexed organic dye ligands, the chelated complexes may bypass sewage treatment systems and are transported long distances. The possibility exists that de-chelation may take place and the freed metal and ligand will independently contribute to ecotoxicity. This made a strong 


\section{Current Trends in Fashion Technology \& Textile Engineering}

case of treatment of wastewater on-site, with three important objectives: decolorize the wastewater, remove the metallic ions, nullify carcinogenicity by dismantling the dye moiety. A simple, low molecular weight mono-azo dye Eriochrome Black T which is also a chelating agent for metallic ions is introduced and recommended to be an experimental dye species for preliminary investigation into technical feasibilities for the treatment of specific dye wastewaters.

\section{References}

1. Baumann H, Hensel HR (1967) Neue Metal lkomplex farbstoffe, Struktur und färberische Eigenschaften. Fortschr Chem Forsch 7: 643783.

2. Beffa F, Back G (1984) Metal complex dyes for wool and nylon - 1930 to date. Rev Prog Coloration 14: 33-42.

3. Hunger K (2003) Industrial Dyes: Chemistry, Properties \& Application (bk). p. 85.

4. Myek B, Adesina OB, Batari ML (2015) Synthesis of New Azo Dye and Its Iron Complex Derived from 3-aminophenol. International Journal of Modern Chemistry 7(1): 54-59.

5. Van N (2016) Novel Metal Complexes of Bispyrazole Azo Dyes for Chemical Fibers. Fibre Chemistry 47(6): 497-500.

6. Hussain G (2017) New acid dyes and their metal complexes based on substituted phenols for leather: Synthesis, characterization and optical studies. Journal of Applied Research and Technology 15: 346-355.

7. El-Wakiel NA (2017) Synthesis and characterization of metal complexes of azo dye based on 5-nitro-8-hydroxyquinoline and their applications in dyeing polyester fabrics. Applied Organometallic Chemistry 31(10).

8. Herbst W, Huger K (2004) Chemistry, Synthesis. Subsection 2.10.1 in Chap. 2 (Metal Complex Pigments) of Industrial Organic Pigments: Production, Properties and Application. pp. 389.

9. Dave PN (2011) Removal of Eriochrome Black T by adsorption onto eucalyptus bark using green technology. Indian Journal of Chemical Technology 18: 53-60.

10. Zollinger H (2003) Color Chemistry: Synthesis, Properties and Applications of Organic Dyes and Pigments. Color Chemistry. pp. 212.

11. Keihei Ueno, Toshiaki Imamura, Cheng KL (1992) CRC Handbook of Organic Analytical Reagents, Second Edition. pp. 163.

12. Douglas A Skoog, Donald M West, James Holler F, Stanley R Crouch (2014) Fundamentals of Analytical Chemistry. Cengage Learning pp 431.

13. Hamed MMA, Ismall NM, Ibrahim SA (1994) Solvent Characteristics in the Spectral Behaviour of Eriochrome Black T Dyes and Pigments 26(4): 297-305.

14. Çakir O, Co Şkun EE, Biçer E, Çakir W (2001) Voltammetric and Polarographic Studies of Eriochrome Black T-Nickel (II) Complex. Turkish Journal of Chemistry 25 (1): 33-38.

15. Masoud MS (2002) Dissociation constants of eriochrme black T and Eriochrome blue black RC indicators and the formation constants of their complexes with Fe (III), Co(II), Ni(II), Cu(II), Zn(II), Cd(II), Hg(II) and $\mathrm{Pb}(\mathrm{II})$,under different temperatures and in presence of different solvents. Thermnochimica Acta 381: 119-131.

16. Herbst W, Hunger K (2004) Chemistry, Synthesis. Subsection 2.10 .1 in Chapter 2 (Metal Complex Pigments) of Industrial Organic Pigments: Production, Properties and Application, Wiley-VCH, USA, pp. 394.

17. Hunger K (2003) Metal complexes as chromophores. Section 2.9 (subsections 2.9.1 and 2.9.2) in Chapter 2: Important chemical chromophores of dye classes, in Industrial Dyes: Chemistry, Properties and Application, Wiley-VCH, USA, pp. 13-112.

18. Zollinger $\mathrm{H}$ (2003) Azo dyes and pigments. Chapter 7 in Color Chemistry. ( $3^{\text {rd }}$ rev. edn.) Wiley-VCH, USA.

19. Herbst W, Hunger K (2004) Chemistry, Synthesis. Chapter 2 (Metal Complex Pigments) of Industrial Organic Pigments: Production, Properties and Application, ( $3^{\text {rd }}$ edn), Wiley-VCH, USA.

20. Holdgate MW, A Perspective of Environmental Pollution. Cambridge University Press, UK, p. 18.

21. https://www.japantimes.co.jp/news/2012/03/18/news/toyamaconcludes-cadmium-cleanup/\#.W6x12mgzbIV

22. Kaji M (2012) Role of experts and public participation in pollution control: the case of Itai-itai disease in Japan. Ethics in Science and Environmental Politics 12: 99-111.

23. Yadav DS, Kumar V, Singh (1986) Inhibition of soil urease activity and nitrification with some metallic cations, Australian Journal of Soil Research 24(4): 527-532.

24. Tai Lee Hu, Wu SC (2001) Assessment of the effect of azo dye RP2B on the growth of a nitrogen fixing cyanobacterium Anabaena sp. Bioresource Technology 77(1): 93-95.

25. Batool S (2015) Effect of azo dye on ammonium oxidation process and ammonia-oxidizing bacteria (AOB) in soil. RSC Adv 5: 34812-34820.

26. Ayed L (2011) Decolorization and degradation of azo dye Methyl Red by an isolated Sphingomonas paucimobilis: Biotoxicity and metabolites characterization. Desalination 274: 272-277.

27. Yoshida $O$ (1971) The Environmental, Health and Economic Impacts of Textile Azo Dyes. United Kingdom Houses of Parliament, Parliamentary Office of Science and Technology (2015) Yoshida O. Bladder cancer in workers of the dyeing industry. Igaku No Ayumi 79: 421-422.

28. Yoshida O, Miyakawa M (1973) Etiology of bladder cancer: Metabolic aspects. In: Analytical and experimental epidemiology of cancer. Baltimore, University Park Press, USA, p. 31-39.

29. Yoshida O, Miyakawa M, Okada Y (1981) The disintegration of a benzidine dye, direct deep black ex, by Escherichia coli and soil bacteria. In: Overcash MR (Ed.), Decomposition of toxic and nontoxic organic compounds in soil. Ann Arbor, Ann Arbor Science Publication, MI, USA, pp. 227-231.

30. Miller B, Silverman DT, Hoover RN, Blair A (1986) Painters' Dye epidemics in USA: Cancer risks among artistic painters. American Journal of Industrial Medicine 9: 281-287.

31. Barry A. Miller, Aaron Blair (1992) Cancer Risks among Artists. Leonardo (Journal of the International Society for the Arts, Sciences and Technology 25(2): 169-173.

32. Silverman DT, Levin LI, Hoover RN, Hartge P (1989) Occupational risks of bladder cancer in the United States: I. White men. J Natl Cancer Inst 81(19): $1472-1480$

33. Lima ROA (2007) Mutagenic and carcinogenic potential of a textile azo dye processing plant effluent that impacts a drinking water source. Gen tox and environ mutagenesis 626: 1-2.

34. European Committee for Standardization (2017) EN ISO 143621:2017: Textiles - Methods for determination of certain aromatic amines derived from azo colorants - Part 1: Detection of the use of certain azo colorants accessible with and without extracting the fibres.

35. European Committee for Standardization (2017). EN ISO 143623:2017: Textiles - Methods for determination of certain aromatic amines derived from azo colorants - Part 3: Detection of the use of certain azo colorants, which may release 4-aminoazobenzene (ISO 14362-3:2017). 


\section{Current Trends in Fashion Technology \& Textile Engineering}

36. Zhou Q (2001) Chemical pollution and transport of organic dyes in water-soil-crop systems of the Chinese Coast. Bull Environ Contam Toxicol 66(6): 784-793.

37. Fang Y X (2012) Assessment of hormonal activities and genotoxicity of industrial effluents using in vitro bioassays combined with chemical analysis. Environmental Toxicology 31(6): 1273-1282.

38. Clarke EA, Anliker R (1984) Safety in Use of Organic Colourants: Health and Safety Aspects. Review of Progress in Coloration and related topics 14: 84-89.

39. Brown D, Hitz HR, Schäfer L (1981) The Assessment of the Possible Inhibitory Effect of Dyestuffs on Aerobic Waste Water Bacteria Experience with a Screening Test. Chemosphere 10(3): 245-261.

40. Grychtol K (2002) Metal Complex Dyes. Standard article in Ullmann's Encyclopedia of Industrial Chemistry, Wiley-VCH Verlag.

41. Gorzka Z, Kraska J, Lawniczak H (1984) Investigations on Kinetics of
Decomposition of Chromium Complex Dyes of 1:2 and 1:1 Types. Dyes and Pigments 5 (4): 263-275.

42. Mrotzeck U, Mischke P, Schwaiger G, Russ W, Sittig M (1990) Process for the Reduction of Heavy Metal Ions in Excess from Aqueous Synthesis Solutions of Water-Soluble Heavy Metal Complex Dyestuffs. United States Patent no. 4,963,660.

43. Cheung P, Williams DR (2015) Separation of Transition Metals and Chelated Complexes in Wastewaters, Environmental Progress \& Sustainable Energy 34(3): 761-783.

44. Cerjan Stefanović S (2004) Removal of metal-complex dyestuffs by croatian clinoptilolite. Studies in Surface Science and Catalysis 154 1900-1906.

45. Li T, Guthrie JT (2010) Colour removal from aqueous solutions of metal-complex azo dyes using bacterial cells of Shewanella strain J18143. Bioresource Technology 101: 4291-4295.

\section{Your next submission with Juniper Publishers will reach you the below assets}

- Quality Editorial service

- Swift Peer Review

- Reprints availability

- E-prints Service

- Manuscript Podcast for convenient understanding

- Global attainment for your research

- Manuscript accessibility in different formats

( Pdf, E-pub, Full Text, Audio)

- Unceasing customer service

Track the below URL for one-step submission https://juniperpublishers.com/online-submission.php 